\title{
Stereoselective Homoallylation of Aldehydes and Ketones
}

Metal-Catalyzed

Asymmetric

Synthesis and

Stereoselective

Reactions

\section{Key words}

homoallylation

nickel

aldehydes

ketones<smiles>[R]C=CC([R7])=C[Pb]</smiles>

(1 equiv)

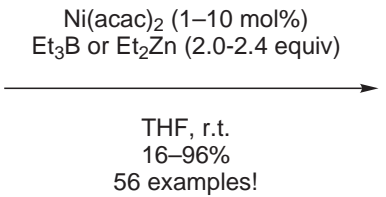<smiles>[R]C=CC([R])C([R])C([2H])([2H])O</smiles>

$\mathrm{dr}=1: 1$ to $100: 0$

$\mathrm{R}^{1}=\mathrm{H}, \mathrm{Alk}, \mathrm{Ar}, \mathrm{OMe}, \mathrm{OSi}(i-\mathrm{Pr})_{3} ; \mathrm{R}^{2}=\mathrm{H}, \mathrm{Alk}, \mathrm{OSi}(\mathrm{Alk})_{3}$

Selected examples: $\mathrm{R}^{3}=\mathrm{H}, \operatorname{Alk}, \mathrm{OSi}(\mathrm{Alk})_{3} ; \mathrm{R}^{4}=\mathrm{Alk}, \mathrm{Ar} ; \mathrm{R}^{5}=\mathrm{H}$, Alk

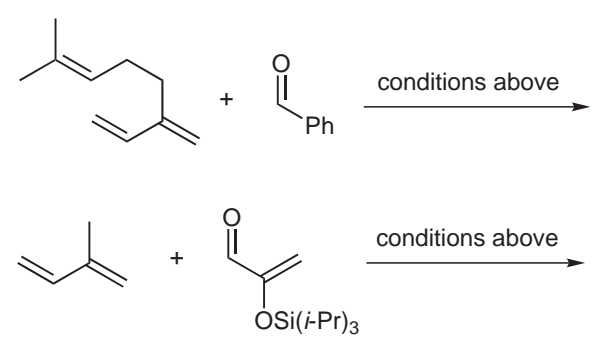<smiles>C=C[C@H](CCC=C(C)C)CC(O)c1ccccc1</smiles>

$90 \%, d r=100: 0$

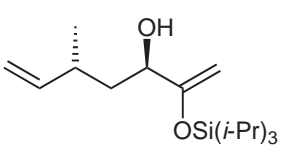

$77 \%, \mathrm{dr}=100: 0$

Significance: In the presence of catalytic Ni(acac) and stoichiometric $\mathrm{Et}_{3} \mathrm{~B}$ or $\mathrm{Et}_{2} \mathrm{Zn}, 1,3$-dienes are added to aldehydes and ketones to stereoselectively afford homoallylation products. Aromatic aldehydes react in the presence of $\mathrm{Et}_{3} \mathrm{~B}$ with 1,3-anti selectivity whereas aliphatic aldehydes react in the presence of $\mathrm{Et}_{2} \mathrm{Zn}$ to give exclusively 1,3-anti products. Terminally substituted dienes generally afford 1,2-anti products, except hydroxyterminal dienes which afford 1,2-syn products. Less reactive moieties such as ketones and cyclohexadiene required $\mathrm{Et}_{2} \mathrm{Zn}$, and afforded the product in moderate yields, with cyclohexadiene affording allylation, not homallylation products. Catalyst loadings as low as $1 \mathrm{~mol} \%$ were used on a $50-\mathrm{mmol}$ scale and the diene loading was decreased to 1.1 equivalents. The method was applied to a 10-g scale reaction of isoprene and dehydrocinnamaldehyde, affording product in $80 \%$ yield.
Comment: This report is a thorough examination of the $\mathrm{Ni}$-catalyzed homoallylation of aldehydes and ketones, which explored nearly all of the factors affecting the reaction. Mechanistically, it is proposed that $\mathrm{Ni}(0)$ coordinates to the diene and aldehyde, promoting aldehyde addition and $\mathrm{Ni}(\mathrm{II})$ $\pi$-allyl formation. Ethyl transfer from $\mathrm{Et}_{3} \mathrm{~B}$ or $\mathrm{Et}_{2} \mathrm{Zn}$ forms an ethylnickel(II) species which undergoes $\beta$-hydride elimination followed by reductive elimination to generate $\mathrm{Ni}(0)$ and the product. 